\title{
Memahami Arti Kata Dan Makna Teologis Yang Terkandung Dalam Kata Masyrik Dan Magrib Pada Nyanyian Kemenangan Iman Nomor 141
}

\author{
Eka Apriyanti, Rohani Siahaan
}

\begin{abstract}
Abstrak
Nyanyian-nyanyian himne dalam buku Nyanyian Kemenangan Iman sekarang sudah mulai ditinggalkan. Selain gereja tidak mewajibkan jemaat untuk menyanyikannya dalam ibadah, juga syair lagu banyak yang tidak dimengerti, bahkan tidak lagi dikenal dalam bahasa sehari-hari. Oleh karena itu, penulis tertarik untuk mengetahui arti kata serta makna teologis dari "Masyrik" dan "Magrib" dalam nyanyian yang berjudul: "Ke Masyrik Ke Magrib".

Setelah memahami latar belakang terciptanya lagu "Ke Masyrik Ke Magrib", penulis memahami bahwa arti kata "Masyrik" dan "Magrib" bermakna bagi pekabaran Injil yang tidak terbatas baik tempat maupun waktu. Penulis juga melampirkan syair baru berdasarkan syair aslinya dan sesuai dengan hasil uraian dari bahasan karya tulis.
\end{abstract}

Kata Kunci: Nyanyian, Makna Teologis, Masyrik, Magrib, The Region Beyond, NKI.

\section{Pendahuluan}

\section{Latar Belakang Masalah}

Waktu penulis masih duduk dibangku SD, lagu yang wajib dinyanyikan dalam ibadah bagi jemaat GKII adalah Nyanyian Kemenangan Iman (NKI). Minggu itu jemaat menyanyi lagu NKI 141, "ke Masyrik ke Magrib". Dengan spontan penulis bertanya, "Ma, apa arti masyrik dan magrib?", ibu penulis menjawab, “mama juga tidak tahu, sudahlah yang penting kita menyanyi saja". Pertanyaan itu pun tidak dilanjutkan lagi, tetapi masih terus tersimpan dalam hati penulis.

Bertahun-tahun setelah penulis masuk bangku SMA, di hari minggu itu jemaat kembali menyanyikan lagu yang sama. Tiba-tiba penulis teringat akan pertanyaan yang belum terjawab beberapa tahun lalu. Selesai ibadah minggu penulis memberanikan diri untuk menanyakan hal yang sama kepada pembina pemuda gereja waktu itu: "bang, apa arti masyrik dan magrib?" jawaban pembina tersebut cukup singkat; "masyrik dan magrib" artinya dari Timur dan Barat, katanya singkat.

Bagi penulis jawaban pembina di atas sangat membantu untuk memenuhi rasa penasaran yang selama ini dipendam. Tetapi muncul pertanyaan lain dalam pikiran penulis, apakah sesimpel itu arti dari kata "masyrik" dan "magrib"? Kalau demikian, mengapa harus menggunakan kata "Masyrik" dan "Margib" untuk menggambarkan Timur dan Barat? Penulis yakin bahwa bukan suatu kesengajaan hal ini dapat terjadi sehingga penulis merasa 
sangat perlu mencari tahu arti kata dan menemukan makna teologis dari kata "Masyrik" dan "Magrib".

Seperti bangsa Israel yang menjadikan musik sebagai gaya hidup mereka yang dimulai dari saat keluar dari Mesir, dalam perjalanan mereka yang jatuh-bangun mereka selalu mengungkapkan perasaan mereka melalui musik: nyanyian, tarian, permainan musik. Mereka memainkan musik dalam peperangan (Kel.15), pada waktu peletakan dasar bait suci (Ezra 3:8-13), dan pada waktu memberontak terhadap Allah pun bangsa Israel bernanyi; menari; dan bermain musik (Kel. 32:17-18). ${ }^{1}$ Menurut Vido Fransisco Pardede,

Secara khusus dari kacamata rohani, musik dapat memberikan dampak yang hebat dalam kehidupan seseorang. Alkitab banyak memberikan contoh bahwa musik memiliki kekuatan dan pengaruh yang besar dalam kehidupan umat manusia. Dengan musik, Daud menyembuhkan raja Saul dari sakit gila yang disebabkan oleh roh jahat (1 Samuel 16:14-23), dengan musik Yosua dan bangsa Israel dapat menghancurkan tembok Yerikho (Yosua 6:1-27) dan dengan nyanyian dan musik Paulus dan Silas dapat terbebas dari penjara dengan cara yang ajaib (Kis 16:19-40). ${ }^{2}$

Nyanyian adalah bagian yang amat penting bukan saja dalam ibadah, melainkan juga dalam seluruh kehidupan iman Kristen. ${ }^{3}$ Karena saat bernyanyi berarti jemaat juga menyatakan dengan iman setiap lirik yang diucapkan, sehingga lewat nyanyian jemaat merasakan kehadiran Allah dalam nyanyian.

Dari sudut ilmu musik, nyanyian jemaat digolongkan sebagai community singing yaitu, nyanyian bersama yang dapat dilakukan secara massal. Sifat maupun tujuan nyanyian jemaat adalah menyatukan seluruh umat secara oukumenis dalam ibadah. Isi nyanyian yang terutama bukan perasaan hati, tetapi kekudusan dan ketulusan pribadi dalam mengakui dan menerima pengasihan Allah atas perbuatan-Nya yang besar terhadap dunia ciptaan-Nya. ${ }^{4}$

Itu sebabnya gereja-gereja pada umumnya mempunyai buku nyanyian jemaat, salah satunya Nyanyian Kemenangan Iman yang dimiliki oleh gereja Kemah Injil Indonesia. Buku NKI adalah kumpulan lagu-lagu ibadah atau himne yang dipergunakan oleh jemaat gereja Kemah Injil Indonesia. Adapun nyanyian-nyanyian yang ada dalam buku NKI sebagian besar bersumber dari buku Hymn of the Christian Life (selanjutnya akan disingkat dengan HCL) yang diterbitkan oleh William Macintosh di Universitas Oxford tahun 1871. ${ }^{5}$

Bagi Gereja Kemah Injil, NKI yang diterbitkan oleh Kalam Hidup merupakan identitas Gereja Kemah Injil Indonesia. Buku ini juga dilengkapi dengan harmoni SATB

${ }^{1}$ Michael Collins dan Matthew A. Price, The Story Of Christianity: Menelusuri Jejak Kristianitas (Yogyakarta: Kanisius, 1999), 19.

2 Vido Fransisco Pardede, "Kekuatan dan Pengaruh Musik," diakses 19 September 2017, http://majalahpraise.com/kekuatan-dan-pengaruh-musik-769.html

${ }^{3}$ Eka Darmaputra, Menyembah Dalam Roh dan Kebenaran: Khotbah-Khotbah Tentang Kehidupan Beribadah dan Bergereja yang Kontekstual (Jakarta: BPK Gunung Mulia, 2007), 8.

${ }^{4}$ Rohani Siahaan, "Memahami Nyanyian Jemaat Sebagai Sentral Musik Gereja Apa Dan Bagaimana?" Jurnal Jaffray 10, No. 2 (Oktober 2012):158, diakses 19 September 2017, http://www.sttjaffray.ac.id/mobile/images/stories/Rohani_Siahaan7.pdf

${ }^{5}$ Hubert Bower, Hymn Of the Christian Life: Studies In English Hymn-Writing (Oxford: William Macintosch, 1871), 20. 
(Sopran, Alto, Tenor, Bass) sehingga lebih memudahkan jemaat untuk dapat menyanyikannya. Pada umumnya, kebanyakan dari lagu-lagu ini, diciptakan oleh tokohtokoh gereja yang berpengaruh yang hidup dekat dengan Allah.

Satu hal yang menarik dari buku NKI adalah syair-syairnya yang sangat puitis dan memiliki makna sangat dalam. Begitu pula pengarang-pengarangnya, antara lain: A. B. Simpson, Fanny Crosby, Charles Wesley, Reginal Heber, William B. Bradbury, dan banyak lagi tokoh lainnya yang baik iman maupun musikalitasnya tidak perlu diragukan, sehingga karya-karya mereka sangat indah dan sakral.

Sama seperti pada umumnya lagu, dalam NKI juga tidak terlepas dari rangkaian katakata yang memiliki nilai estetika, motivasi, doa dan pengajaran teologi, karena itu kata-kata dalam lagu sangat penting untuk menjelaskan makna teologia lagu tersebut. Tetapi karena dalam sebuah lagu pengarang sangat terbatas untuk bisa memberi penjelasan secara panjang dan detail tentang makna syair lagu sehingga, penggunaan kata dan penulisannya harus jelas dan singkat. Misalnya, seperti terjemahan suatu lirik dari Bahasa Sumber $(B S U)^{6}$ ke Bahasa Sasaran $(\mathrm{BSA})^{7}$, seyogyanya dapat dipahami oleh penerima lagu.

Berdasarkan hasil wawancara acak via telepon yang dilakukan penulis terhadap 38 orang yang terdiri dari 21 mahasiswa, 12 alumni STT Jafray Makassar dan 5 orang aktivis gereja - pelayan mimbar dan pemusik gereja - dengan pertanyaan pertama: seberapa sering lagu "Ke Masyrik Ke Magrib" dinyanyikan digereja saudara? Sebanyak 18 orang menjawab "kadang-kadang, paling di bulan misi", sebanyak 15 orang menjawab "sering", sebanyak 4 orang menjawab"tidak pernah". Pertanyaan kedua: tahukah Saudara arti Masyrik dan Magrib? Sebanyak 14 orang menjawab "tidak tahu", sebanyak 12 orang menjawab "tahu sedikit" dan sebanyak 12 orang menjawab "tahu". Jadi, penulis melihat bahwa jumlah orang yang tidak mengerti arti kata "Masyrik" dan "Masyrik" lebih banyak dan kebanyakan dari mereka mengakui bahwa lagu ini dinyanyikan hanya pada saat bulan misi.

Penulis juga mewawancarai via telepon seorang dosen STT jaffray Makassar yang berasal dari USA tepatnya di Toccoa, Georgia. Dengan pertanyaan apakah lagu The Region Beyond sering dinyanyikan di gereja tempat miss berasal? Miss Kara Gruber menjawab, "Mungkin di gereja saya masih menyanyi lagu itu tapi tidak sering. Mungkin untuk gereja yang lain sudah tidak menyanyi lagi karena lagu itu kurang terkenal dibandingkan dengan lagu-lagu A. B. Simpson yang lain.” Dengan kata lain, di Indonesia lagu The Region Beyond yang diterjemahkan menjadi "Ke Masyrik Ke Magrib" lebih sering dinyanyikan dibandingkan gereja CM\&A sendiri. Padahal, makna teologis dari lagu ini sangat dalam.

\section{Pokok Masalah}

Berdasarkan uraian di atas, pokok masalah yang akan dibahas dalam penulisan karya ilmiah ini adalah:

Pertama, bagaimana latar belakang terciptanya lagu "ke Masyrik ke Magrib"?

Kedua, bagaimana terjemahan arti kata masyrik dan magrib berdasarkan lirik asli?

Ketiga, bagaimana arti kata masyrik dan magrib serta makna teologis bagi pembaca?

${ }^{6}$ BSU berarti Bahasa Sumber. Ninip Hanifah, "Teori Penerjemahan Sebagai Dasar Pembelajaran Penerjemahan Studi Kualitatif Etnografi” Jurnal Cakrawala Pendidikan XXXV, No. 2 (Juni 2016):259, diakses 20 April 2018, https://media.neliti.com/mediapublications/81043-ID-none-pdf

${ }^{7}$ BSA berarti Bahasa Sasaran. Ninip Hanifah, "Teori Penerjemahan Sebagai Dasar Pembelajaran Penerjemahan Studi Kualitatif Etnografi” Jurnal Cakrawala Pendidikan XXXV, No. 2 (Juni 2016):259, diakses 20 April 2018, https://media.neliti.com/mediapublications/81043-ID-none-pdf 


\section{Tujuan Penelitian}

Tujuan penelitian karya ilmiah ini adalah: Magrib".

Pertama, untuk mengetahui latar belakang terciptanya lagu NKI 141 "ke Masyrik ke

Kedua, untuk memahami arti kata dan makna teologis dari kata masyrik dan magrib.

Ketiga, untuk menemukan makna teologis dari kata masyrik dan magrib pada syair Nyanyian Kemenangan Iman nomor 141.

\section{Manfaat Penelitian}

Adapun manfaat penelitian yang hendak dicapai melalui penelitian karya ilmiah ini adalah:

Pertama, agar pembaca mengetahui latar belakang, sekaligus memahami makna syair atau arti, serta makna teologis lagu "ke Masyrik ke Magrib" dari NKI 141.

Kedua, melalui karya tulis ini menjadi pertimbangan sekiranya lagu "ke Masyrik ke Magrib" NKI 141 akan direvisi.

Ketiga, untuk memenuhi salah satu syarat dalam menyelesaikan strata satu (S-1) Program Studi Teologi Kristen, Konsentrasi Musik Gerejawi di Sekolah Tinggi Theologia Jaffray Makassar.

\section{Metode Penelitian}

Metode penelitian yang digunakan dalam penulisan karya ilmiah ini adalah metode kualitatif dengan menggunakan metode pengumpulan data melalui penelitian kepustakaan, buku nyanyian HCL dan NKI sebagai sumber utama, Alkitab, buku tafsiran, buku-buku musik, jurnal, wawancara acak via telpon serta berbagai literatur yang berhubungan dengan pembahasan karya ilmiah penulis.

Bab 1 pendahuluan penulis meneliti secara kepustakaan dari berbagai sumber buku, jurnal dan wawancara via telpon terhadap 38 orang. Bab 2 penulis meneliti secara kepustakaan dari berbagai sumber buku dan jurnal untuk mencari latar belakang Dr. A. B. Simpson dan nyanyiannya. Bab 3 Analisis syair penulis membandingkan lirik asli dalam HCL dengan terjemahan lagu dalam NKI untuk melihat konteks lagu berdasarkan keseluruhan syair. Bab 4 memahami arti kata "masyrik" dan "magrib" secara etimologis kemudian mengartikan makna teologisnya berdasarkan nas Alkitab dan beberapa buku tafsiran. Bab 5 kesimpulan dan saran.

tafsiran. Bab 5 kesimpulan dan saran.

\section{Batasan Penelitian}

Pada penelitian ini penulis hanya membahas makna kata atau syair maupun makna teologis dari kata masyrik dan magrib dalam lagu NKI 141 "ke Masyrik ke Magrib".

\section{Kesimpulan}

Berdasarkan pemaparan pada bab-bab sebelumnya, penulis menarik beberapa poin penting yang menjadi kesimpulan dalam karya ilmiah ini. Kesimpulan tersebut adalah:

Pertama, latar belakang terciptanya lagu NKI 141 berdasarkan mimpi yang diartikannya sebagai panggilan dari Tuhan bagi dirinya untuk pergi memberitakan Injil, 
keluar dari tempatnya yang nyaman, masuk ke tengah-tengah kelompok orang yang belum mengenal Kristus.

Kedua, syair asli dengan terjemahannya sangat berbeda dari bait pertama hingga bait keempat begitu juga dengan refreinnya. Namun demikian, pesan dari tiap bait masih tetap dipertahankan. Bait $1 \mathrm{I}$, bait $2 \mathrm{He}$, bait $3 \mathrm{You}$, bait 4 lost sheep. Metode yang digunakan dalam menterjemahkan ini adalah metode adaptasi, di mana penerjemah menelusuri makna dan menekankan pada isi pesan.

Ketiga, kata "magrib" bukan berasal dari bahasa Indonesia, tetapi sudah menjadi bagian dari bahasa Indonesia. Dalam Kamus Besar Bahasa Indonesia arti "magrib", adalah Barat, arah matahari terbenam. Syamsul Hadi dalam bukunya Kata-Kata Arab Dalam Bahasa Indonesia menulis, "masyrik" adalah Timur (negeri-negeri sebelah Timur).

Keempat, setiap lagu yang diciptakan oleh A. B. Simpson merupakan cerminan dari isi hatinya tentang perjalanan imannya bersama Yesus. Salah satu dari sekian banyak lagulagu ciptaannya yang sampai sekarang ini memberkati banyak orang, adalah lagu yang menjadi pokok bahasan dalam karya ilmiah ini, yaitu: The Region Beyond yang dikenal jemaat dalam buku NKI 141 "Ke Masyrik Ke Magrib".

Kelima, selama ini, jemaat menyanyikan lagu Ke Masyrik Ke Magrib dengan tidak memahami arti kata dan makna "Masyrik" dan "Magrib" tersebut. Hal ini karena kata "Masyrik" dan "Magrib" tidak digunakan lagi dalam bahasa sehari-hari. Padahal sebagai pemimpin dan pelayan di gereja, sebaiknya dapat memberi penjelasan mengenai arti dari lagu-lagu yang dinyanyikan oleh jemaat. Jika hal ini diabaikan maka kemungkinan di generasi berikutnya NKI akan ditinggalkan karena lagu "Ke Masyrik Ke Masyrik" hanyalah satu dari 304 lagu dalam buku NKI yang tidak menggunakan bahasa sehari-hari.

Dengan demikian dari kelima poin di atas, makna tologis dari kata "masyrik" dan "magrib" adalah sebuah pesan bagi seluruh jemaat Tuhan supaya: Memberitakan Injil hingga ujung dunia (Kis. 1:8) dan memberitakan Injil selama masih ada waktu (Yoh. 9:4).

\section{Kepustakaan}

Blackstone, Barry. The Region Beyond: From The Land Down Under. USA: Resource Publications, 2012.

Bower, Hubert. Hymn Of the Christian Life: Studies In English Hymn-Writing. Oxford: William Macintosch, 1871.

Darmaputra, Eka. Menyembah Dalam Roh dan Kebenaran: Khotbah-Khotbah Tentang Kehidupan Beribadah dan Bergereja yang Kontekstual. Jakarta: BPK Gunung Mulia, 2007.

Dixon, R. Tafsiran Kisah Para Rasul. Malang: Gandum Mas, 2005.

Guthrine, Donald., Dkk. Tafsiran Alkitab Abad ke-21: Jilid 3 Injil Matius-Wahyu. Jakarta: YKBK, 2017.

Hadi, Syamsul. Kata-Kata Arab Dalam Bahasa Indonesia. Yogyakarta: Universitas Gajah Mada, 2015. 
Hanifa, Ninip. "Teori Penerjemahan Sebagai Dasar Pembelajaran Penerjemahan Studi Kualitatif Etnografi." Jurnal Cakrawala Pendidikan XXXV, 2 (Juni 2016):254-263. Diakses 20 April 2018. https://media.neliti.com/mediapublications/81043-ID-nonepdf

Henry, Matthew. Tafsiran Matthew Henry: Injil Yohanes 1-11. Surabaya: Momentum, 2010. Henry, Matthew. Tafsiran Surat Roma, 1 dan 2 Korintus. Surabaya: Momentum, 2005.Henry,

Hymn Of Christian Life. USA: Christian Publications Inc, 1962.

Matthew. The New Commentary. Jakarta: P. D. Nilankadi, 1983.

Jacobs, Tom. Paulus: Hidup, Karya dan Teologinya. Yogyakarta: Kanisius, 1983.

Keisling, Gary. Relentless Spirituality: Embracing The Spiritual Diciplines of A. B. Simpson. USA: An Imprint of Moody Publishers, 2004.

Nienkierchen, Charles W. A. B. Simpson and the Pentecostal Movement: A Study in Continuity, Crisis, and Change. Eguene: Wipf and Stock Publishers, 1992.

Nyanyian Kemenangan Iman. Bandung: Yayasan Kalam Hidup, 2013.

Price, Matthew A. dan Michael Collins. The Story Of Christianity: Menelusuri Jejak Kristianitas. Yogyakarta: Kanisius, 1999.

Shaldily, Hassan dan John M. Echols. Kamus Inggris Indonesia. Jakarta: Gramedia Pustaka Utama, 2010.

Siahaan, Rohani. "Memahami Nyanyian Jemaat Sebagai Sentral Musik Gereja Apa Dan Bagaimana?" Jurnal Jaffray 10, 2 (Oktober 2012):157-165. Diakses 19 September 2017. http://www.sttjaffray.ac.id/mobile/images/stories/Rohani_Siahaan7.pdf

Thompson, A. E. A. B. Simpson:Pelayanan dan Karyanya . Bandung: Kalam Hidup, 2009.

Tozer, A. W. Wingspread. A. B. Simpson: A Study In Spiritual Altitude. Christian Publications, Inc: USA 1943.

Travis, Drake. Healing Power Voice Activated. USA: Creation House, 2009.

Wiersbe, Warren W. Hidup Bersama Firman: Pasal demi Pasal Seluruh Alkitab. Yogyakarta: Yayasan Gloria, 2011.

Wijaya, Hengki. Analisis Data Kualitatif. Makassar: Sekolah Tinggi Theologia Jaffray, 2018.

Wright, Tom. Kisah Para Rasul Untuk Seтиa Orang. Jakarta: Literatur Perkantas, 2011. 